\title{
When, where and whom: assessing wildlife attacks on people in Chitwan National Park, Nepal
}

\author{
Thakur Silmal, Jaromir Kolejka, Bharat P. Bhatta, Santosh Rayamajhi \\ RAM P. SHARMA and BUdDi S. POUDEL
}

\begin{abstract}
Wildlife attacks on people in and around protected areas have become one of the main challenges for wildlife management authorities. We assessed all correlates of wildlife attacks during 2003-2013 in the vicinity of Chitwan National Park, Nepal. We used data from various sources (discussion with stakeholders, field observations, questionnaire surveys). Wildlife attacks were significantly correlated to factors such as site, season and time, activity, gender and awareness. Moreover, $89 \%$ of recorded attacks occurred outside the Park. The number of attacks fluctuated widely and patterns of attacks were significantly uneven across seasons and months. Of the $87 \%$ of attacks that occurred during the day, $63 \%$ occurred in the morning. Most victims were male and c. $45 \%$ of attacks occurred when people were collecting forest resources or working on croplands. Attacks were carried out predominantly by rhinoceros Rhinoceros unicornis (38\%), tigers Panthera tigris (21\%), sloth bears Melursus ursinus (18\%), elephants Elephas maximus (9\%) and wild boar Sus scrofa (8\%). The people attacked lived close to the Park, depended on farming for their livelihoods, and had little knowledge of animal behaviour. Attacks can be mitigated through proper management of habitats inside the Park and raising awareness of wildlife behaviour among local people. We recommend establishing a participatory emergency rescue team to deal with problematic animals in high-risk areas.
\end{abstract}

Keywords Buffer zone, high-risk areas, human-wildlife conflict, problem animals, wildlife attack correlates, wildlife victims

To view supplementary material for this article, please visit http://dx.doi.org/10.1017/So030605315001489

THAKUR SilwaL ${ }^{*}$ (Corresponding author) and JARomir KolejKa Department of Geography, Masaryk University, Porici 7, 60300, Brno, Czech Republic

E-mail thakur.silwal@gmail.com

Bharat P. Bhatta Policy Research in Development and Economics, Kathmandu, Nepal

SAntosh RaYamajhi Tribhuvan University, Institute of Forestry, Pokhara, Nepal Ram P. Sharma Czech University of Life Sciences Prague, Faculty of Forestry and Wood Sciences, Prague, Czech Republic

BuddI S. Poudel School of Environmental Sciences, Charles Sturt University, Albury, New South Wales, Australia

*Also at: Tribhuvan University, Institute of Forestry, PO Box 43, Pokhara, Nepal

Received 15 September 2015. Revision requested 2 November 2015.

Accepted 23 December 2015. First published online 10 May 2016.

\section{Introduction}

Wildlife attacks on people in the buffer zones of protected areas are one of the major obstacles to gaining public support for conservation in landscapes where resource use by people and wildlife overlaps. Human populations in tiger Panthera tigris range countries in Asia have doubled in the last few decades and people increasingly come into contact with tigers (Nyhus \& Tilson, 2004; Inskip \& Zimmermann, 2009) and other animals. Meanwhile, cases of livestock depredation and damage to crops and property are increasing (DNPWC, 2012; Karanth et al., 2012). Infrastructural development and industrial and agricultural expansion have adverse impacts on wildlife habitats, which result in human-wildlife conflict, including attacks by wildlife.

As habitat becomes fragmented the interface between people and wildlife increases, and wildlife populations become confined to insular refugia. Wildlife come into contact and conflict with people more frequently as they seek to fulfil their nutritional, ecological and behavioural needs (Sukumar, 1990; Gubbi et al., 2016). In and around Chitwan National Park in Nepal there has been an increase in encounters between people and wildlife, particularly rhinoceros Rhinoceros unicornis, tigers, sloth bears Melursus ursinus, elephants Elephas maximus and wild boar Sus scro$f a$, sometimes with life threatening results (CNP, 2012). The Park is Nepal's first protected area and supports the largest populations of the species most commonly involved in attacks on people (120 tigers, 605 rhinoceros, c. 60 elephants, 250 sloth bears; CNP, 2012; DNPWC, 2012; CNP/NTNCBCC, 2015; GON, 2015).

Several studies, mostly focused on single species, have investigated attacks by wildlife on people (Gurung et al., 2008; Carter, 2013; Pant et al., 2015), and made recommendations to improve the conservation practices in and around the Park. The greatest challenge in the conservation of mega species is to minimize conflict with people and damage to livestock and property. It is not possible to eliminate the risk of wildlife attacks completely, and thus the objective is to reduce it to a level that people can accept. The fourth amendment to the Nepal National Parks and Wildlife Conservation Act 1973 aims to address some of these issues by accommodating a communitybased integrated conservation and development approach and increasing the level of tolerance of damage caused by wildlife through sharing $30-50 \%$ of the revenue collected by parks with communities living in their buffer zones 
(GON, 1973, 1996; DNPWC, 1999a, 2012). Buffer zone management committees are legally elected to mobilize local communities to implement conservation programmes, with overall responsibility for planning, resource distribution and conflict mitigation (DNPWC, 1999a, 2012). However, these committees invest more funds in community development than conflict mitigation (Silwal et al., 2013). Communities have also taken over the management of buffer zone forests, thus extending available wildlife habitat beyond park boundaries (Budhathoki, 2003, 2004; Gurung et al., 2008) and providing dispersal corridors for tigers (Sharma et al., 2011), rhinoceros, elephants and other wildlife (CNP/ NTNC-BCC, 2015; Pant et al., 2015).

To our knowledge no studies in Chitwan National Park have adequately investigated major attacking species, the factors that influence attacks, or the impacts of attacks on victims' activities. There has been no investigation of spatial and temporal distributions of attacks by individual species, or combinations of influencing factors. We analysed incidents of attacks by wildlife in the Park for the period 2003-2013 to record the spatial distribution and temporal pattern of wildlife attacks, to assess social factors and other characteristics of the victims, and to recommend ways to reduce people's vulnerability to wildlife attacks and increase human-wildlife co-existence.

\section{Study area}

Chitwan National Park (932 km² ; Fig. 1a) was established in 1973 and includes part of the Siwalik Hills and floodplains, at an altitude of $150-815 \mathrm{~m}$ (DNPWC, 2012). An area of 750 $\mathrm{km}^{2}$ comprising $45 \%$ forests and 55\% agricultural lands surrounding the Park was declared a buffer zone in 1996 (DNPWC, 1999b). The climate is tropical, with a subtropical summer monsoon; mean temperature is $25-34^{\circ} \mathrm{C}$. The Park connects the wildlife habitat of India's Valmiki Tiger Reserve in the south to the Mahabharata foothills to the north through the Brandabhar corridor, which is the only remaining north-south corridor used by wildlife to access upland ecosystems. The Park includes pristine habitat for threatened species, including the rhinoceros, tiger and elephant, and various birds and reptiles. Its importance is recognized internationally; it is designated a Ramsar site and a UNESCO World Heritage Site. Among Nepal's 20 protected areas, it generates the highest amount of revenue, mainly from tourism (DNPWC, 2010).

The Park is divided into four management sectors (Fig. 1b): eastern (Sauraha), central (Kashara), western (Amaltari) and southern (Madi). The buffer zone is home to c. 250,000 people and $>150,000$ livestock, with 34 Village Development Committees and two municipalities (DNPWC, 1999b, 2012). Local livelihoods are based predominantly on subsistence agriculture, livestock farming and fishing, and this is consistent across most ethnic groups (e.g. Brahmin, Kshetri, Tamang, Tharu, Danuwar, Praja); however, the Bote and Darai own little or no farmland and are more dependent on fishing than other activities (Sharma, 1991; Budhathoki, 2012).

\section{Methods}

We made preliminary field visits, organized group discussions, interviewed key stakeholders and conducted a questionnaire survey to collect information about wildlife attacks that occurred in and around Chitwan National Park during 2003-2013. The field study was conducted during September 2013-March 2014. We used documents from the Park office, the Buffer Zone Management Committee and Buffer Zone User Committees as secondary data sources. The purpose of the preliminary field visit was to share our objectives with the management authorities of the Park and buffer zone and elicit feedback about attacks by wildlife in and around the Park. These authorities maintain up-to-date records of attacks (GON, 2015), and they provided us with demographic information about the victims. Prior to conducting a household survey we organized meetings at 33 settlements affected by wildlife attacks, and held discussions with local communities. The participants included buffer zone management representatives, victims, local community leaders and others. Discussions mainly focused on the trend of species-specific wildlife damage, including human casualties, ongoing prevention and mitigation practices, and the effectiveness of controlling the access of wildlife to the settlements. We conducted interviews with 36 key stakeholders (six park officials, 27 buffer zone representatives, and three officials from conservation partner organizations (WWF-Terai Arc Landscape Program, National Trust for Nature Conservation) to elicit their opinions on wildlife attacks, existing management practices and the improvements needed. Incorporating feedback from the preliminary field visit, group discussions and key stakeholder interviews, we prepared questionnaires in Nepalese and conducted face-to-face interviews with victims of wildlife attacks in 128 settlements. Relatives and eyewitnesses were also interviewed if victims were unable to provide information. In total we interviewed 115 victims and 214 relatives/eyewitnesses, having obtained prior verbal consent from the victims. None of the interviewees declined to provide information. Five minors provided consent to be interviewed via their guardians. All interviewees were assured of confidentiality. The victims ranged in age from 4 months to 82 years and $75 \%$ were male. We recorded the location, with a global positioning system, of each incident site, with the help of victims or their representatives, or eyewitnesses. We did not record the location of a victim's household unless the attack occurred at home. 

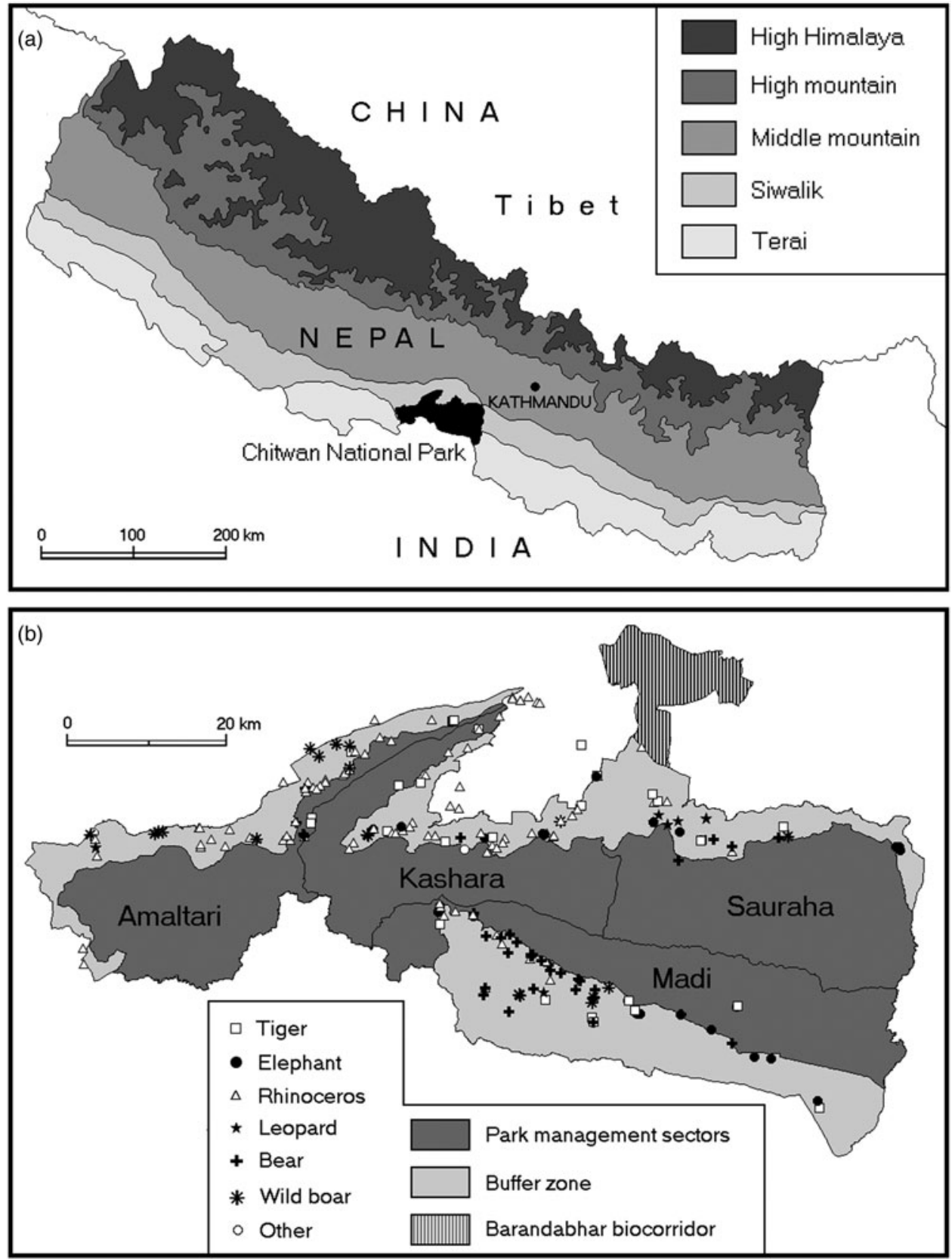

FIG. 1 (a) Location of Chitwan National Park in Nepal. (b) Distribution of wildlife attacks on people in and around the Park during 2003-2013.

We performed data analyses using descriptive statistics in Excel (Microsoft, Redmond, USA) and SPSS v. 22.0 (IBM, Armonk, USA). Having examined incident locations, time of attacks and various characteristics of victims we performed associative statistical analysis (Kelly, 1985) to identify the variables that were correlated to wildlife attacks. Using a null hypothesis of equal distribution of frequency among seasons and months, we generated the number of wildlife attacks expected in each season and month by dividing the total number of attacks by the number of seasons and months. We compared observed and expected numbers of attacks using a $\chi^{2}$ test (Montgomery et al., 2001). We exported the location coordinates of each incident site to
ArcGIS v. 10.3 (ESRI, Redlands, USA), superimposed the data on the topographical map of the study area (GON, 1993) and performed spatial analyses.

\section{Results}

There were a total of 329 attacks by wildlife on people in and around Chitwan National Park during 2003-2013 (Table 1). The highest number of attacks $(n=48)$ occurred in 2010 and the lowest $(n=16)$ in 2006. There was considerable variation between years, with a mean of 30 attacks year ${ }^{-1}$. However, there was an increasing trend in number of attacks since 
TABLE 1 Number of attacks by wildlife species on people in and around Chitwan National Park, Nepal (Fig. 1), annually during $2003-2013$.

\begin{tabular}{|c|c|c|c|c|c|c|c|c|}
\hline Year & $\begin{array}{l}\text { Rhinoceros } \\
\text { Rhinoceros unicornis }\end{array}$ & $\begin{array}{l}\text { Tiger } \\
\text { Panthera } \\
\text { tigris }\end{array}$ & $\begin{array}{l}\text { Sloth bear } \\
\text { Melursus ursinus }\end{array}$ & $\begin{array}{l}\text { Elephant Elephas } \\
\text { maximus }\end{array}$ & $\begin{array}{l}\text { Wild boar } \\
\text { Sus scrofa }\end{array}$ & $\begin{array}{l}\text { Leopard } \\
\text { Panthera pardus }\end{array}$ & Others ${ }^{\star}$ & Total \\
\hline 2003 & 17 & 5 & 1 & 3 & 0 & 0 & 0 & 26 \\
\hline 2004 & 7 & 9 & 8 & 2 & 0 & 0 & 0 & 26 \\
\hline 2005 & 14 & 5 & 7 & 1 & 1 & 4 & 1 & 33 \\
\hline 2006 & 6 & 2 & 6 & 2 & 0 & 0 & 0 & 16 \\
\hline 2007 & 8 & 4 & 1 & 1 & 3 & 1 & 1 & 19 \\
\hline 2008 & 12 & 4 & 4 & 2 & 2 & 6 & 0 & 30 \\
\hline 2009 & 12 & 9 & 6 & 1 & 7 & 0 & 0 & 35 \\
\hline 2010 & 15 & 5 & 10 & 9 & 2 & 6 & 1 & 48 \\
\hline 2011 & 11 & 5 & 8 & 2 & 2 & 1 & 0 & 29 \\
\hline 2012 & 13 & 11 & 5 & 4 & 4 & 0 & 1 & 38 \\
\hline 2013 & 11 & 9 & 3 & 1 & 5 & 0 & 0 & 29 \\
\hline Total & $126(38 \%)$ & $68(21 \%)$ & 59 (18\%) & $28(9 \%)$ & $26(8 \%)$ & $18(5 \%)$ & $4(1 \%)$ & $329(100 \%)$ \\
\hline
\end{tabular}

${ }^{*}$ Gaur bison Bos gaurus, sambar deer Rusa unicolor and marsh crocodile Crocodylus palustris

2008. Most of the attacks (89\%) occurred outside the Park (Fig. 2a). The majority of the attacks (74\%) occurred within $1 \mathrm{~km}$ of the Park boundary (Fig. 2b). More than one-third of the attacks $(37 \%)$ occurred in the buffer zone community forests, followed by cropland, villages and other areas (e.g. water sources, trails; Fig. 2c).

Nine species were identified as major attackers: rhinoceros, tiger, sloth bear, elephant, wild boar, leopard Panthera pardus, gaur bison Bos gaurus, sambar deer Rusa unicolor and marsh crocodile Crocodylus palustris. Rhinoceroses were responsible for the greatest number of attacks (38\%), followed by tigers, sloth bears, elephants, wild boar, leopards and others (Table 1).

The highest number of attacks $(30 \%)$ occurred in the Madi sector, followed by the Kashara, Amaltari and Sauraha sectors (Fig. 1b). Attacks by all nine species were recorded in the Madi sector. In contrast, there were no attacks by elephants in Amaltari. Most of the attacks by sloth bears (75\%) and $50 \%$ of attacks by elephants occurred in Madi. The highest number of attacks by rhinoceroses and tigers occurred in Kashara and Amaltari.

The attacks varied by year (Table 1; Fig. 2a) and season (Fig. 3a). Patterns of attacks were significantly uneven across seasons and months $(\mathrm{P}<0.001)$. More than one-third of attacks occurred during winter (39\%), with only a few during autumn (14\%). The highest number of attacks occurred in December (17\%), followed by January, May and April (Fig. 3b). Most of the attacks (63\%) on both male and female victims occurred during the late morning, followed by early morning (Supplementary Table S1). However, patterns varied significantly between species $(\mathrm{P}<0.001)$. Most attacks (tiger, 41\%; leopard, 61\%; sloth bear, 39\%; wild boar, $38 \%$ ) occurred in late morning and afternoon. Approximately half of the attacks by rhinoceroses occurred in early morning $(48 \%)$, with $22 \%$ in late morning. However, $50 \%$ of attacks by elephants occurred at night, with $31 \%$ of attacks
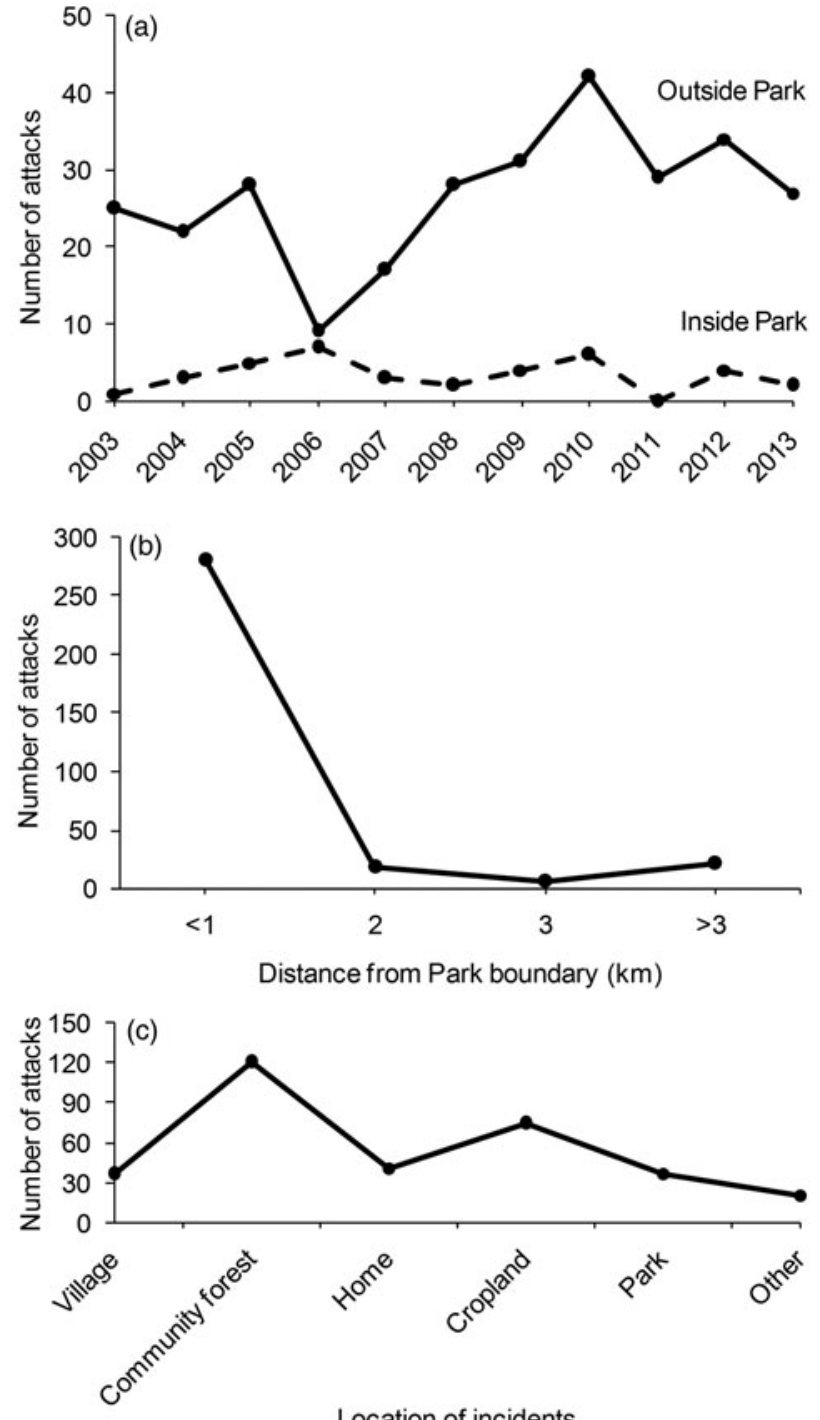

Location of incidents

FIG. 2 Trends of wildlife attacks on people in and around Chitwan National Park (Fig. 1) by (a) year, (b) distance from Park boundary, and (c) location of incident. 

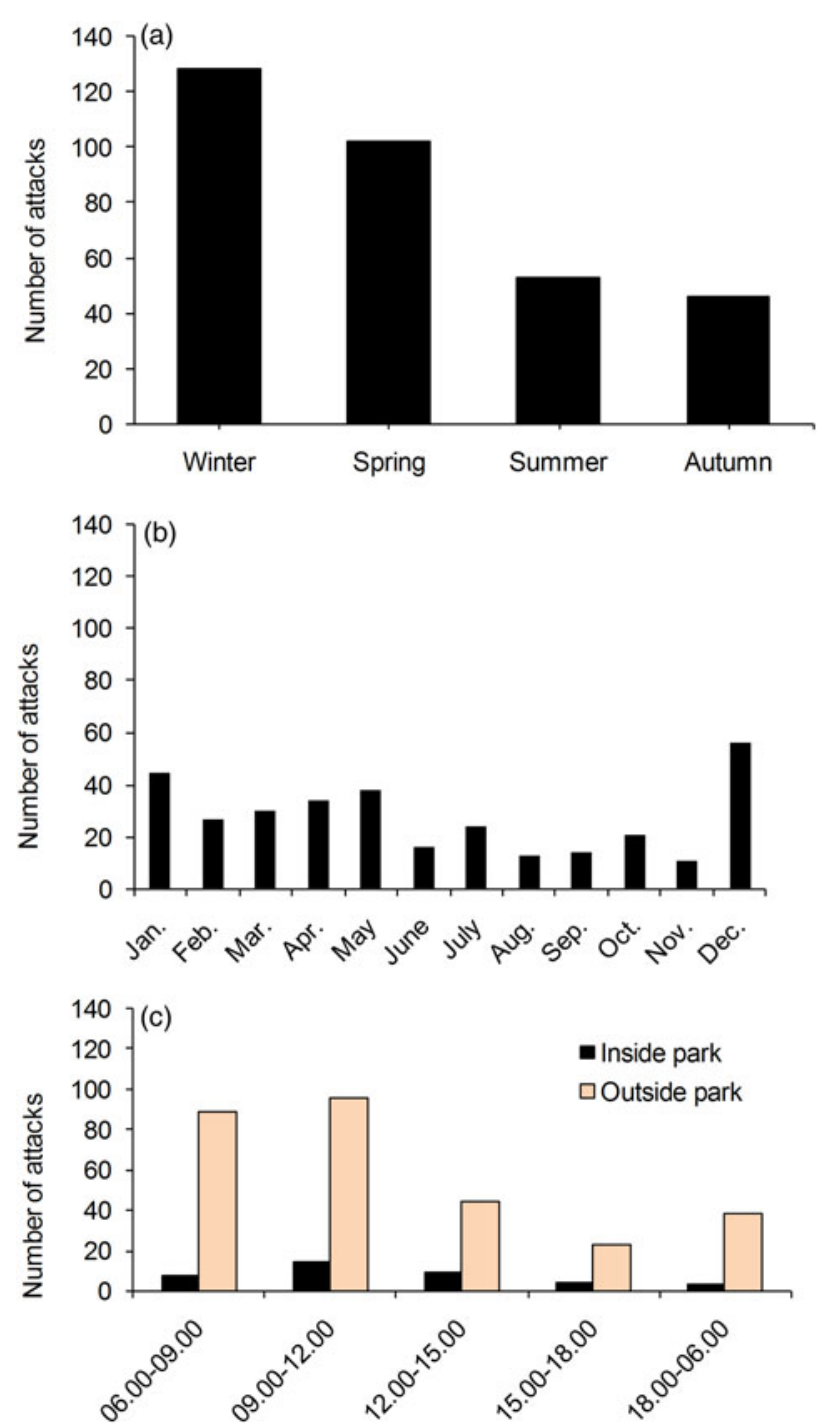

FIG. 3 Temporal patterns of wildlife attacks on people in and around Chitwan National Park (Fig. 1) during 2003-2013, by (a) season, (b) month, and (c) time.

in the late morning. Outside the Park more incidents occurred in the late morning (33\%), with relatively fewer in the early morning ( $31 \%$; Fig. 3 c). However, most of the attacks occurred inside the Park in the late morning (38\%), with fewer in the afternoon $(24 \%)$. There were significant differences in the number of attacks on males and females, and seniors and juniors $(\mathrm{P}<0.001)$. Most of the victims were male $(75 \%), 77 \%$ were adults, $14 \%$ seniors and $8 \%$ teens, with two $<9$ years. Victims were aged 4 months -82 years, with a mean age of 42 years. Most victims were $40-49$ years of age (Supplementary Table S2). More than $50 \%$ of victims had never been to school and were illiterate. Of the remainder, $24 \%$ had attended school for $<5$ years, $22 \%$ for $6-10$ years, and only $4 \%$ for $>10$ years. Fifty-four percent of female victims and $48 \%$ of male victims were illiterate. Most of the victims (86\%) were unaware of the behaviour of the attacking animals; a few had a basic awareness
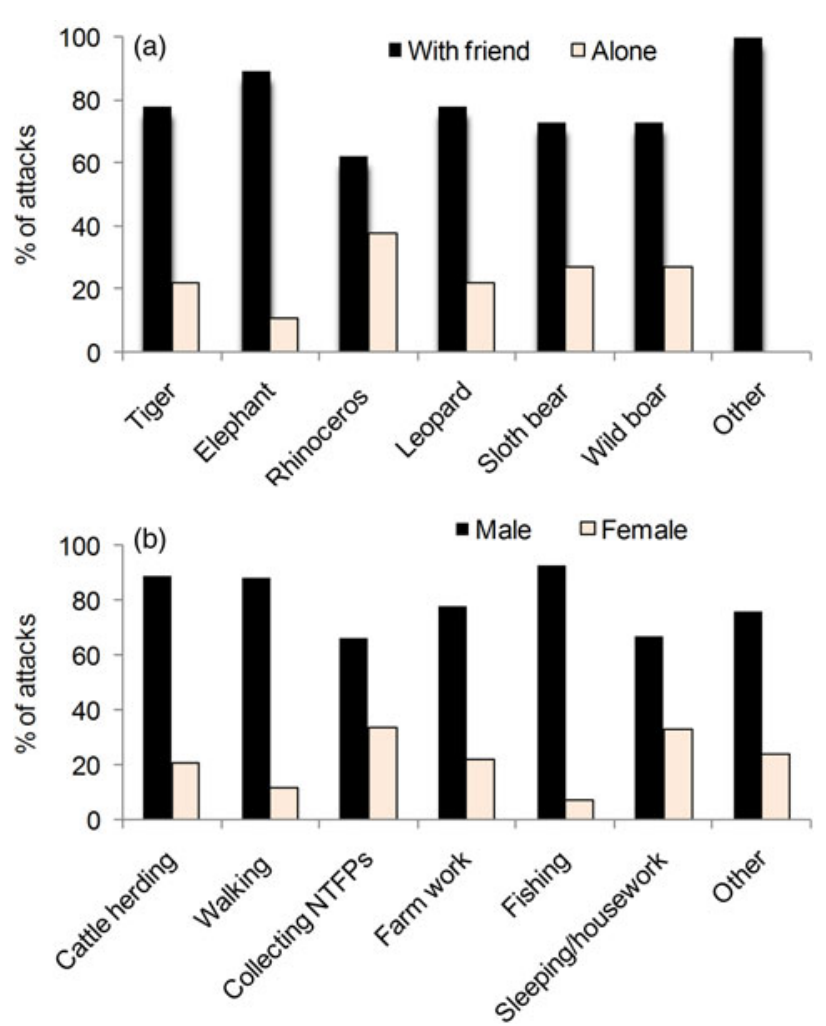

FIG. 4 Percentage of wildlife attacks on people in and around Chitwan National Park (Fig. 1) during 2003-2013 by (a) species and whether victims were alone or with friends and (b) activity and sex of victims.

and were thus able to avoid attacks, or sustained only minor injuries.

Most of the attacks (71\%) occurred when the victims were with a friend or in a group (Fig. 4a), which in some cases prevented them from being fatally injured. In five cases (two attacks by tigers, two by bears and one by wild boar) victims were rescued by friends. Attacks occurred most commonly while victims were collecting forest resources, either within or outside the Park (Fig. 4b). Some victims (12\%) were attacked in their homes, mostly by elephants while they were sleeping at night in poorly built houses or huts. More than $60 \%$ of all attacks were by elephants.

\section{Discussion}

Every year during 2003-2013 a mean of 30 people were attacked in and around Chitwan National Park, sustaining minor to fatal injuries. The number of attacks fluctuated but there was a steady increase in attacks since 2008 (Table 1). Potential causes include increased populations of the main attacking species (rhinoceros, tiger), increased mobility of elephants, habitat destruction as a result of invasive plant species inside the Park and habitat improvement in the buffer zone community forests (DNPWC, 2012; CNP/ 
NTNC-BCC, 2015; Pant et al., 2015). The invasive plant Mikania micrantha affects $40 \%$ of habitat in the Park, with $>50 \%$ coverage in $15 \%$ of the affected area (Murphy et al., 2013). Grassland coverage in the Park decreased from 20 to $12 \%$ during $1970-2013$ (CNP, 2013). The increase in attacks in the buffer zone community forests and croplands (Budhathoki, 2004; Gurung et al., 2008; DNPWC, 2012) indicates that attacking animals, including rhinoceroses and bears, are moving out of the Park as it becomes increasingly difficult to find suitable food, shelter and breeding sites within the Park as a result of habitat destruction and human interference (DNPWC, 2012; CNP, 2013; CNP/NTNC-BCC, 2015).

Our results indicate that the number of attacks has increased over time in buffer zone forests (Fig.2b). In the early 1990 os forests adjoining the Park were degraded as a result of over exploitation, and a large number of cattle grazed freely. Since 1996, however, local communities have taken responsibility for conserving these forests, and wildlife habitats have improved (Budhathoki, 2003; Gurung et al., 2008). The increased availability of resources in the forests may have attracted both people and wildlife, resulting in an increase in human-wildlife conflict.

Our results indicate that most attacks occur close to villages near the Park (Fig. 2b), which corroborates the results of previous studies (Pant et al., 2015). A high number of attacks may also be attributed to the roaming habits of some wildlife (e.g. elephants, rhinoceroses, tigers) to find better habitats in the buffer zone forests, where they come into contact with people (Nyhus et al., 2005; Pant et al., 2015). This explains the increasing trend in wildlife attacks as habitats in the buffer zone community forests and Barandabhar corridor are improved (Supplementary Table $\mathrm{S}_{3}$ ). Nepal is committed to the Global Tiger Initiative, which aims to double the tiger population in Asia by 2022 (GON, 2010; Global Tiger Initiative Secretariat, 2012); however, this may result in increased conflict between people and tigers. Alternative strategies are needed to promote coexistence between people and wildlife, and could include changing cropping patterns, creating physical barriers to deter wildlife from entering settlements, deploying rescue teams, and raising awareness among local people.

Patterns of attack were similar across species, with most attacks occurring in the morning time. However, most attacks by elephants occurred at night in December and January (Fig. 3), which is consistent with findings from central Nepal (Pant et al., 2015). Encounters between people and rhinoceroses tend to occur in the early morning, when rhinoceroses are leaving the croplands after foraging on paddy, wheat and lentils.

The number of people killed by tigers during 2003-2013 (3.5 per year) was lower than reported for 1998-2006 (7.2 per year; Gurung et al., 2008) and higher than that reported in Bardia National Park for 1994-2007 (o.9 per year; Bhattarai
\& Fischer, 2014). The tiger population in the Park increased from an estimated 91 in 2009 to 120 in 2013 (CNP, 2013). Likewise, the rhinoceros population increased from 372 in 2005 to 605 in 2015 (CNP/NTNC-BCC, 2015), and we recorded a higher number of attacks by rhinoceroses compared with previous studies (Jnawali, 1989; Gurung, 2004). The increasing trends in attacks by rhinoceroses may be attributable to an increase in the rhinoceros population in the Park and the improved habitat in the buffer zone forests. Only $4 \%$ of fatal attacks in our study were caused by wild boar, and two people were attacked aggressively by one wild boar in a single incident.

Most victims were attacked while working on cropland and collecting forest resources, indicating that their outdoor activities make them more vulnerable to attack (Fig. 4b), which is consistent with the results of previous studies (Nyhus \& Tilson, 2004; Gurung et al., 2008; Dhanwatey et al., 2013; Pant et al., 2015). Illiterate people have limited opportunities to find other jobs and are dependent on collecting forest resources and agriculture for their livelihoods. However, people argued that formal education and literacy alone may be insufficient protection against attacks by wildlife. The few victims who stated they had knowledge about wildlife behaviour succeeded in avoiding major injuries from attacks.

Our findings can help stakeholders formulate strategies for reducing human casualties and launch an insurance scheme against damage caused by wildlife. Potential strategies could include community-based insurance schemes for medical treatment and monthly incentives for potential victims of wildlife, support for education and income generation, changes in cropping patterns and livestock husbandry, and participatory rescue teams. The distribution (Fig. 1b) and temporal patterns (Fig. 3) of attacks may be used to improve existing prevention and mitigation practices rather than providing benefits to victims after incidents have occurred. Finding effective ways to reduce casualties should be the first management priority (e.g. a live monitoring system using mobile phone alerts was used to mitigate human-elephant conflict in Valpari in southern India; Karanth et al., 2012).

Chitwan National Park is distinct among Nepal's protected areas because it generates the largest amount of income annually (USD 2.5 million in 2014-2015, Park records), of which $50 \%$ is invested directly in the buffer zone. Most of the funds are invested in community development rather than in addressing conflict issues (Silwal et al., 2013) because of obligations under management guidelines (DNPWC, 1999a). We discussed this with Park authorities and buffer zone representatives during the presentation of our preliminary results and all participants agreed to allocate $25 \%$ of the Park's total revenue to conflict management. To reduce wildlife attacks in Chitwan and similar landscapes, even though the physical and social factors may 
vary, we recommend (1) educating local communities in high-risk areas about the behaviour and movements of particular species, and how to minimize risk; (2) regulating and limiting human movement and activities in buffer zone forests and in the vicinity of protected areas; and (3) establishing a well-equipped participatory emergency rescue team comprising professional personnel and local people to monitor wildlife in high-risk areas, provide warnings of imminent danger, and rescue victims.

\section{Acknowledgements}

We are indebted to the victims of wildlife attack around Chitwan National Park who consented to being interviewed for this study. We thank the Department of National Parks and Wildlife Conservation for permission to carry out the research, and the park and buffer zone representatives who provided valuable information. We thank Chloe Inskip, Bishnu C. Poudel and Purbaj Pant for their valuable comments, and Bikash Pathak for his effort in collecting field data. Funding was received from The Rufford Small Grants Foundation, WWF Education for Nature Faculty Fellowship, and the Institute of Forestry/ComForM Project. We thank Masaryk University, Department of Geography, for providing financial support to present this research at the International Conference on Forests, Soil and Rural Livelihoods in a Changing Climate, at Kathmandu University in September 2014.

\section{References}

Bhattarai, B.R. \& Fischer, K. (2014) Human-tiger Panthera tigris conflict and its perception in Bardia National Park, Nepal. Oryx, 48, 522-528.

BudhathoKi, P. (2003) A category V protected landscape approach to buffer zone management in Nepal. Parks, 13, 22-30.

BUDHATHOKI, P. (2004) Linking communities with conservation in developing countries: buffer zone management initiatives in Nepal. Oryx, 38, 334-341.

BuDHATHOKI, P. (2012) Developing conservation governance strategies: holistic management of protected areas in Nepal. $\mathrm{PhD}$ thesis. University of Greenwich, London, UK. Http://gala.gre.ac.uk/9453/1/ Prabhu_Budhathoki_2012.pdf [accessed 25 May 2015].

CARTER, N. (2013) Coupled human and natural systems approach to tiger conservation in Chitwan, Nepal and beyond. $\mathrm{PhD}$ thesis. Michigan State University, Lansing, USA. Http://etd.lib.msu.edu/ islandora/object/etd\%3A2090/datastream/OBJ/view [accessed 16 June 2015].

CNP (Chitwan National Park) (2010) Chitwan National Park: Annual Report- Fiscal Year 2066/67 (2009/2010). Department of National Parks and Wildlife Conservation, Chitwan, Nepal.

CNP (Chitwan National Park) (2011) Chitwan National Park: Annual Report- Fiscal Year 2067/68 (2010/2011). Department of National Parks and Wildlife Conservation, Chitwan, Nepal.

CNP (Chitwan National Park) (2012) Chitwan National Park: Annual Report- Fiscal Year 2068/69 (2011/2012). Department of National Parks and Wildlife Conservation, Chitwan, Nepal.
CNP (Chitwan National Park) (2013) Chitwan National Park: Annual Report- Fiscal Year 2069/70 (2012/2013). Department of National Parks and Wildlife Conservation, Chitwan, Nepal.

CNP/NTNC-BCC (Chitwan National Park \& National Trust For Nature Conservation-Biodiversity Conservation Center) (2015) National Rhino Count 2015. Field report submitted to WWF Nepal, Chitwan, Nepal.

Dhanwatey, H.S., Crawford, J.C., Abade, L.A.S., Dhanwatey, P.H., Nielsen, C.K. \& Sillero-Zubiri, C. (2013) Large carnivore attacks on humans in central India: a case study from the Tadoba-Adhari Tiger Reserve. Oryx, 47, 221-227.

DNPWC (Department of National Park and Wildlife Conservation) (1999a) Buffer Zone Management Guidelines. DNPWC, Kathmandu, Nepal.

DNPWC (Department of National Park and Wildlife Conservation) (1999b) Resource Profile of Chitwan National Park and Buffer Zone. DNPWC, Kathmandu, Nepal.

DNPWC (Department of National Park and Wildlife Conservation) (2010) Annual Report 2009-2010. DNPWC, Kathmandu, Nepal.

DNPWC (Department of National Park and Wildlife Conservation) (2012) Chitwan National Park and Buffer Zone Management Plan 2012-2016. DNPWC, Kathmandu, Nepal.

Global Tiger Initiative Secretariat (2012) Global Tiger Recovery Programme Implementation Report 2012. The World Bank, Washington, DC, USA.

GON (Government of Nepal) (1973) The National Parks and Wildlife Conservation Act 1973 (4th amendment in 1993). Kathmandu, Nepal.

GON (Government of Nepal) (1993) The Topographic Map of Chitwan National Park and Buffer Zone. Survey Department, Kathmandu, Nepal.

GON (Government of Nepal) (1996) Buffer Zone Management Rules 2052 (1996). Kathmandu, Nepal.

GON (Government of Nepal) (2010) National Tiger Recovery Programme (NTRP): $T \times 2$ by 2022. Kathmandu, Nepal.

GON (Government of Nepal) (2015) Wildlife Damage Relief Guideline 2013 (1st Amendment 2015). Ministry of Forest and Soil Conservation, Kathmandu, Nepal.

Gubbi, S., Mukherjee, K., Swaminath, M.H. \& Poornesha, H.C. (2016) Providing more protected space for tigers Panthera tigris: a landscape conservation approach in the Western Ghats, southern India. Oryx, 50, 336-343.

Gurung, B., Smith, J.L.D., McDougal, C., Karki, J.B. \& Barlow, A. (2008) Factors associated with human-killing tigers in Chitwan National Park, Nepal. Biological Conservation, 141, 3069-3078.

GURUNG, M.K. (2004) Human dimensions in one-horned rhinoceros conservation in Royal Chitwan National Park, Nepal. MSc thesis. University of Natural Resources and Applied Sciences, Vienna, Austria.

Inskip, C. \& Zimmermann, A. (2009) Human-felid conflict: a review of patterns and priorities worldwide. Oryx , 43, 18-34

JNAWALI, S.R. (1989) Park and people conflict: assessment of crop damage and human harassment by rhinoceros (Rhinoceros unicornis) in Sauraha area adjacent to the Royal Chitwan National Park. MSc thesis. Agricultural University of Norway, Ås, Norway.

Karanth, K.K., Gopalaswamy, A.M., DeFries, R. \& Ballal, N. (2012) Assessing patterns of human-wildlife conflicts and compensation around a central Indian protected area. PLOS ONE, 7 (12), e50433.

Karanth, K.U. \& Gopal, R. (2005) An ecology-based policy framework for human-tiger coexistence in India. In People and Wildlife: Conflict or Coexistence? (eds R. Woodroffe, S. Thirgood \& 
A. Rabinowitz), pp. 373-387. Cambridge University Press, New York, USA.

Kelly, R.M. (1985) The Associative Group Analysis method and evaluation research. Evaluation Review, 9, 35-50.

Montgomery, D.C., Peck, E.A. \& Vining, G.G. (2001) Introduction to Linear Regression Analysis. 3rd edition. Wiley, New York, USA.

Murphy, S.T., Subedi, N., Jnawali, S.R., Lamichhane, B.R., UpADHYAy, G.P., Kock, R. \& AMin, R. (2013) Invasive mikania in Chitwan National Park, Nepal: the threat to the greater one-horned rhinocerous Rhinocerous unicornis and factors driving the invasion. Oryx, 47, 361-368.

Nyhus, P.J. \& Tilson, R. (2004) Characterizing human-tiger conflict in Sumatra, Indonesia: implications for conservation. Oryx, 38, 68-74.

Nyhus, P.J., Osofsky, S.A., Ferraro, P., Madden, F. \& Fischer, H. (2005) Bearing the costs of human-wildlife conflict: the challenges of compensation schemes. In People and Wildlife: Conflict or Coexistence? (eds R. Woodroffe, S. Thirgood \& A. Rabinowitz), pp. 107-121. Cambridge University Press, New York, USA.

Pant, G., Dhakal, M., Pradhan, N.M.B., Leverington, F. \& Hockings, M. (2015) Nature and extent of human-elephant Elephas maximus conflict in central Nepal. Oryx, in press. Http://dx. doi.org/10.1017/Soo30605315000381

Sharma, B.K., Chalise, M.K. \& Solanki, G.S. (2011) Large wildlife population in Baghmara Buffer Zone Community Forest, Nepal. Ecoprint, 18, 55-62.

Sharma, U.R. (1991) Park-people interactions in Royal Chitwan National Park, Nepal. PhD thesis. University of Arizona, Tucson,
USA. Http://arizona.openrepository.com/arizona/bitstream/10150/ 185701/1/azu_td_9210308_sip1_m.pdf [accessed 11 August 2015].

Silwal, T., Shrestha, B.P., Bhatta, B.P. \& Devkota, B.P. (2013) Revenue distribution pattern and park-people conflict in Chitwan National Park, Nepal. Banko Janakari, 23, 35-41.

SuKUmaR, R. (1990) Ecology of the Asian elephant in southern India. II. Feeding habits and crop raiding patterns. Journal of Tropical Ecology, 6, 33-53.

\section{Biographical sketches}

THAKUR SILWAL is interested in exploring the gaps between conservation and local livelihoods. JAROMIR KOLEJKA is interested in geographical information systems and landscape mapping, and their application to research and disaster management. BHARAT BHATTA is an economist interested in linking economics to natural resource management. Santosh Rayamajhi has developed management plans for national parks and buffer zones in Nepal. He is interested in livelihood analysis, and monitoring and evaluation of communitybased biodiversity conservation projects. RA M $S_{H A R M A}$ is a silviculturist and is interested in ecological modelling, modelling forest growth and site productivity, and forest management. BUDDI POUDEL has experience in protected area management and is interested in linking research in wildlife ecology and human society. 